\title{
Bronchoalveolar lavage fluid findings in patients with chronic hepatitis $C$ virus infection
}

\author{
Keishi Kubo, Shinji Yamaguchi, Keisaku Fujimoto, Masayuki Hanaoka, \\ Muneharu Hayasaka, Takayuki Honda, Takeshi Sodeyama, Kendo Kiyosawa
}

\begin{abstract}
Background - Hepatitis C virus (HCV) infection has recently been incriminated as an aetiological agent in idiopathic pulmonary fibrosis. This study was performed to determine the cellularity and lymphocyte phenotypes of bronchoalveolar lavage (BAL) fluid in patients with chronic hepatitis $\mathbf{C}$.

Methods - BAL fluid and lavage lymphocyte subsets from 13 patients ( 10 men) with active chronic hepatitis $\mathrm{C}$, diagnosed by sustained elevated serum glutamic pyruvic transaminase and typical histological findings in the liver, were analysed. Lavage findings in these patients were compared with those from 13 healthy volunteers (eight men) as controls.

Results - There was no difference in total cell counts in lavage fluid between the two groups. Lavage lymphocyte and eosinophil numbers were increased in patients with chronic hepatitis C. Surface marker analysis of the lymphocyte populations showed increases in CD2, CD3, CD4, and HLA-DR. CD4/CD8 ratios were not different.

Conclusions - The numbers of lymphocytes and eosinophils in BAL fluid are increased in patients with chronic hepatitis C. These findings suggest that HCV infection may trigger alveolitis.

(Thorax 1996;51:312-314)
\end{abstract}

Keywords: bronchoalveolar lavage, hepatitis C virus, idiopathic pulmonary fibrosis, alveolitis.

Central Clinical

Laboratories

T Honda

Second Department of Internal Medicine

T Sodeyama

K Kiyosawa

Shinshu University School of Medicine, 3-1-1 Asahi,

Matsumoto 390, Japan

Correspondence to: Dr K Kubo.

Received 16 May 1995 Returned to authors Returned to auty 1995 .

Revised version received 14 August 1995

Accepted for publication 3 October 1995 Idiopathic pulmonary fibrosis (IPF) is characterised by inflammation and fibrosis of the pulmonary interstitium and peripheral air spaces. ${ }^{1}$ The aetiology of IPF remains unknown. One interesting and important possible cause is viral infection. ${ }^{2}$ Hepatitis $\mathrm{C}$ virus (HCV), the RNA virus discovered in $1989,{ }^{3}$ is the cause of non-A, non-B hepatitis. One of the pathological manifestations of $\mathrm{HCV}$ is fibrotic changes in the liver. ${ }^{4}$ Ueda $e t a l^{5}$ have reported an unusually high prevalence of serum antibodies to HCV in Japanese patients with IPF, and speculated that HCV may play an important part in the pathogenesis of IPF. How- ever, Irving and coworkers ${ }^{6}$ have suggested that $\mathrm{HCV}$ infection is no more prevalent in patients with IPF than in the general population in the UK.

To elucidate whether HCV infection is related to the pathogenesis of IPF, we investigated the cellularity and lymphocyte phenotypes of bronchoalveolar lavage (BAL) fluid, and performed pulmonary function tests in patients with chronic hepatitis $\mathrm{C}$.

\section{Methods}

SUBJECTS

Thirteen patients ( 10 men) of median age 57 years (range 31-64) with chronic hepatitis C proven by the typical histological findings observed within the previous six months and the presence of sustained elevated serum levels of glutamic pyruvic transaminase (GPT) for at least six months were studied. All patients were positive for antibody to $\mathrm{HCV}$ in serum and negative for hepatitis B surface antigen. They were treated with interferon after this study. The following patients were excluded from the study: those who had received a course of antiviral or immunosuppresive therapy which may lead to alveolitis within six months; those who had a positive titre for autoantibodies to collagen diseases; those who exhibited leucopenia $(<3000 / \mathrm{ml})$ and thrombopenia $(<80000 / \mathrm{ml})$. None of the patients had a familial history of IPF and none had pulmonary fibrosis as determined from symptoms, physical signs, and radiographic findings. Thirteen healthy volunteers (eight men) of median age 49 years (range 24-67) acted as controls.

Subjects in both groups were defined as
BRONCHOALVEOLAR LAVAGE (BAL)

Subcutaneous injections of atropine $(0.5 \mathrm{mg})$ and pethidine hydrochloride $(0.5 \mathrm{mg} / \mathrm{kg})$ were given. The oral pharynx and upper airway was anaesthetised with $2 \%$ lignocaine (lidocaine). 
Table 1 Mean (SE) demographic and physiological characteristics of the study population

\begin{tabular}{lllllll}
\hline & $\begin{array}{l}\text { Number } \\
\text { (men) }\end{array}$ & $\begin{array}{l}\text { Age } \\
\text { (range) } \\
\text { (years) }\end{array}$ & $\begin{array}{l}\text { Smoking } \\
(S, E S)\end{array}$ & $\begin{array}{l}\text { VC } \\
(\% \text { predicted })\end{array}$ & $\begin{array}{l}F E V_{1} / F V C \\
(\%)\end{array}$ & $\begin{array}{l}\text { TLCO } \\
\text { (\% predicted })\end{array}$ \\
\hline HCV & $13(10)$ & $\begin{array}{l}57(3) \\
(31-64)\end{array}$ & 5,3 & $99 \cdot 3(15 \cdot 6)$ & $82 \cdot 6(5 \cdot 3)$ & $95 \cdot 7(16 \cdot 3)$ \\
Control & $13(8)$ & $\begin{array}{l}49(4) \\
(24-67)\end{array}$ & 4,0 & & & \\
\hline
\end{tabular}

$\mathrm{HCV}=$ chronic hepatitis $\mathrm{C} ; \mathrm{VC}=$ vital capacity $\mathrm{FEV}_{\mathrm{1}} / \mathrm{FVC}=$ forced expiratory volume in one second; TLCO = diffusing capacity for carbon monoxide; $S=$ current smoker; $E S=$ ex-smoker.

Table 2 Mean (SE) surface marker analysis of lymphocytes from BAL fluid

\begin{tabular}{|c|c|c|c|c|c|c|c|}
\hline & $\begin{array}{l}C D 2 \\
(\%)\end{array}$ & $\begin{array}{l}C D 20 \\
(\%)\end{array}$ & $\begin{array}{l}C D 3 \\
(\%)\end{array}$ & $\begin{array}{l}C D 4 \\
(\%)\end{array}$ & $\begin{array}{l}C D 8 \\
(\%)\end{array}$ & $\begin{array}{l}H L A-D R \\
(\%)\end{array}$ & $\begin{array}{l}C D 4 / C D 8 \\
\text { (ratio) }\end{array}$ \\
\hline $\begin{array}{l}\mathrm{HCV} \\
(n=13)\end{array}$ & $90.5(1.8)^{*}$ & ${ }^{*} 1 \cdot 7(0 \cdot 6)$ & $79 \cdot 8(3 \cdot 1)^{*}$ & $* 57 \cdot 8(5 \cdot 1)^{*}$ & $* 22 \cdot 7(4 \cdot 1)$ & $54 \cdot 8(3 \cdot 2)^{*}$ & ${ }^{*} 5.09(1.62)$ \\
\hline $\begin{array}{l}\text { Control } \\
(n=13)\end{array}$ & $61 \cdot 3(6 \cdot 9)$ & $1 \cdot 6(0 \cdot 3)$ & $51 \cdot 8(7 \cdot 4)$ & $36 \cdot 8(4 \cdot 9)$ & $16 \cdot 2(3 \cdot 4)$ & $24 \cdot 7(4 \cdot 4)$ & $3.75(0.89)$ \\
\hline
\end{tabular}

$\mathrm{HCV}=$ chronic hepatitis $\mathrm{C}$.

${ }^{*} \mathrm{p}<0.05$ between the two groups.

A fibreoptic bronchoscope (Olympus BF 1T, ED $6 \mathrm{~mm}$, Olympus Co, Tokyo, Japan) was wedged in the middle lobe segmental bronchus. Three $50 \mathrm{ml}$ aliquots of sterile normal saline warmed to $37^{\circ} \mathrm{C}$ were instilled into the lung and each aliquot was then removed by gentle suction. The BAL fluid was filtered through gauze. One small aliquot was used for counting total cell numbers. Another aliquot was spun in a cytometer at $500 \mathrm{rpm}$ for five minutes and stained with the May-Grunwald-Giemsa stain to identify cell populations. Five hundred cells, excluding epithelial cells, were identified per slide to establish differential cell counts and counts were expressed as percentages and total numbers of dividing cell types. The rest of the BAL fluid was centrifuged at $300 \mathrm{~g}$ for 10 minutes at $4^{\circ} \mathrm{C}$ and the supernatant removed. The BAL fluid pellets were analysed for lymphocyte subsets. The cell subsets were analysed by flow cytometry using $\mathrm{CD} 2, \mathrm{CD} 3$, CD4, CD8, CD20, and HLA-DR monoclonal antibodies $^{7}$ (Becton Dickinson Co, Mountain View, California, USA).
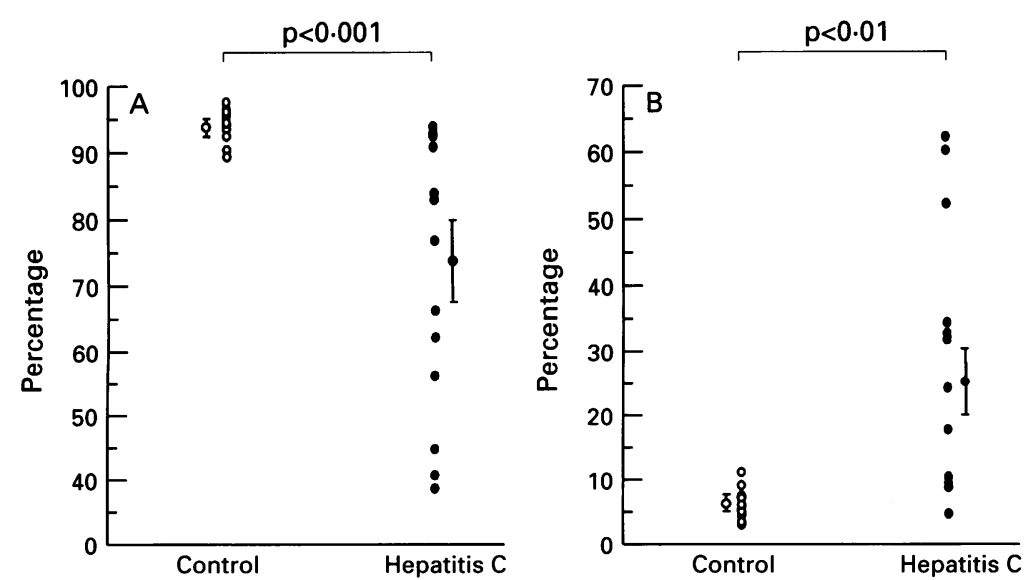

Percentages of $(A)$ macrophages and $(B)$ lymphocytes in bronchoalveolar lavage fluid in normal healthy volunteers $(n=13)$ and patients with chronic hepatitis $C(n=13)$. Vertical lines and bars show mean values and $S E$, respectively, in each group.
PULMONARY FUNCTION TESTS

Spirometric tests were performed for all patients with chronic hepatitis $\mathrm{C}$ using a water spirometer (Gadart Exprograph, GodartStatham, Bilthoven, Holland). Vital capacity (VC) and percentage forced vital capacity expired in one second $\left(\mathrm{FEV}_{1} / \mathrm{FVC}\right)$ were calculated. Carbon monoxide diffusion capacity (TLCO) was measured by the single breath method (Pulmorecorder, model R1551S, Anima, Tokyo, Japan). VC and TLco were expressed as a percentage of the predicted values.

STATISTICAL ANALYSIS

Values in the text, tables, and figure are expressed as means (SE). For statistical analysis Wilcoxon's non-parametric rank sum test was used for comparison between the groups and Spearman's rank correlation test for testing the relationship between variables. A $p$ value of $<0.05$ was considered significant for all tests.

\section{Results}

The demographic and pulmonary function test data of patients with chronic hepatitis $\mathrm{C}$ (HCV group) and normal healthy volunteers are summarised in table 1 . The HCV group had normal pulmonary function in terms of $\% \mathrm{VC}, \mathrm{FEV}_{1} \%$, and TLCo values.

Cell concentrations and surface marker analysis of lymphocytes from BAL fluid are summarised in the figure and table 2. The total cell counts in the BAL fluid from the $\mathrm{HCV}$ and control groups were not significantly different $\left(146.8(27 \cdot 1)\right.$ and $147.5(59.3) \times 10^{3} / \mathrm{ml}$, respectively). However, lymphocyte counts and percentages were significantly higher in the HCV group $\left(49.8 \quad(8.4) \times 10^{3} / \mathrm{ml} ; 24.4\right.$ $(96.2) \%)$ than in the controls $\left(7 \cdot 0(2 \cdot 4) \times 10^{3} /\right.$ $\mathrm{ml} ; 5 \cdot 2(0.7) \% ; \mathrm{p}<0.05)$. Eosinophil counts and percentages were also significantly higher in the HCV group $\left(1.89(0.84) \times 10^{3} / \mathrm{ml} ; 2.0\right.$ $(1 \cdot 2) \%)$ than in the controls $\left(0.03(0.01) \times 10^{3 /}\right.$ $\mathrm{ml} ; 0 \cdot 1(0.0) \% ; \mathrm{p}<0.05)$. Neutrophil counts were not significantly different in the $\mathrm{HCV}$ group $\left(1.1(0.4) \times 10^{3} / \mathrm{ml}\right)$ and controls $(1.5$ $\left.(0 \cdot 5) \times 10^{3} / \mathrm{ml}\right)$. Surface marker analysis of lymphocytes demonstrated significant increases in CD2, CD3, CD4, and HLA-DR. The markers CD20 and CD8 were not increased in the HCV group. The CD4/CD8 ratio was comparable, being $5.09(1.62)$ in the HCV group and 3.75 $(0 \cdot 89)$ in the controls. There was no significant correlation between serum GPT levels and the total or percentages of lymphocytes in the BAL fluid (data not shown).

\section{Discussion}

This study has shown that patients with chronic hepatitis $C$ had a significantly increased total number and percentage of lymphocytes and eosinophils in the BAL fluid, although total cell counts did not differ from those of the normal individuals. Furthermore, surface marker analysis of lymphocytes in the BAL fluid from patients with chronic hepatitis C showed increases in CD2, CD3, CD4, and 
HLA-DR. We believe that smoking had little effect on the cell populations in the BAL fluid since the number of current smokers was similar in both groups and the cell populations of ex-smokers were almost identical to those who had never smoked. ${ }^{8}$

The increased lymphocyte number in patients with chronic hepatitis $\mathrm{C}$ was identified as $\mathrm{T}$ cells $(\mathrm{CD} 2+$ and $\mathrm{CD} 3+)$ and the $\mathrm{T}$ helper/inducer subset of $\mathrm{T}$ cells $(\mathrm{CD} 4+)$. The number of lymphocytes expressing HLA-DR, a marker of early $T$ cell activation, was also increased. The numbers of T suppressor/cytotoxic cells (CD8) and B lymphocytes (CD20) were not increased. The CD4/CD8 ratio showed a tendency to be higher in patients with chronic hepatitis C compared with controls. There have been no previous studies of lymphocyte subsets in BAL fluid or peripheral blood lymphocytes in patients with chronic hepatitis C. However, the findings of our study are consistent with the work of Pham et al who showed higher CD4/CD8 ratios in liver-derived lymphocytes from patients with chronic hepatitis $\mathrm{B}$. The CD4/CD8 ratio of $3.75(0.89)$ found in our normal controls is higher than the control values of $1 \cdot 4-2 \cdot 7$ in other laboratories. ${ }^{8}$ There is no clear explanation for this which is a consistent finding in the control studies in our unit.

The findings of increased eosinophils may be of importance in the pathogenesis of chronic hepatitis C. Eosinophils contain highly cytotoxic products which may be involved in tissue damage. ${ }^{10}$ Peterson et al ${ }^{11}$ reported that eosinophilia $(10 \cdot 7(2 \cdot 7) \%)$ in the BAL fluid predicted a deterioration in vital capacity in patients with IPF. The increase in eosinophils in the BAL fluid in this study $(1.99(1.22) \%)$, although lower than in the IPF study, may nonetheless suggest a role for eosinophils in the development of alveolitis and/or pulmonary fibrosis in patients with chronic hepatitis C.

The relationship of $\mathrm{HCV}$ infection to IPF has been described in two studies. ${ }^{56}$ Ueda et $a l^{5}$ found that 19 of $66(28 \cdot 8 \%)$ Japanese patients with IPF were positive for serum antibodies to HCV using the screening ELISA method (first generation). This percentage of positive findings was significantly higher than that in 9464 age matched control subjects (3.66\%), and the authors speculated that HCV infection might play an important part in the pathogenesis of IPF. By contrast, Irving et $a l^{6}$ reported that only one of 62 patients with IPF was positive for $\mathrm{HCV}$ by second generation anti-HCV ELISA. The discrepancy between the two studies may be due to three factors. Firstly, different methods were used for determining the serological reaction to $\mathrm{HCV}$; secondly, raised IgG levels have been shown to be a cause of false positive anti-c100 results ${ }^{12}$ and the differing IgG profiles in the studies by Ueda and Irving may account for some of the discrepancy in anti-HCV results; and thirdly, there may be geographical differences in the pathogenesis of IPF that could be due to differences between the genotypes of HCV virus ${ }^{13} 14$ which influence the clinical course of hepatitis $\mathrm{C}$ and the response to interferon therapy. We have no data from viral cultures of BAL fluid or lung tissue in patients with IPF to support the hypothesis of HCV infection triggering IPF, but Geist and Hunninghake ${ }^{2}$ have emphasised the possibility of latent viral infection in the development of pulmonary fibrosis, and IPF in particular.

In summary, we have shown significantly increased levels of lymphocytes, mainly active $\mathrm{T}$ cells, and eosinophils in the BAL fluid of patients with chronic hepatitis $\mathrm{C}$ and no clinical evidence of lung disease, which suggests that $\mathrm{HCV}$ infection might be a trigger of active alveolitis which can lead to pulmonary fibrosis.

We acknowledge the help and suggestions of Drs T Kobayashi Y Okubo, Y Matsuzawa, T Koizumi, S Yoshikawa, S Horie, $\mathrm{K}$ Okada, T Hayano, T Miyahara, E Sato, $H$ Nomura, and $Y$ Yamazaki. This work was supported in part by a Grant-in-Aid for Scientific Research (C), No.06670606, from the Ministry of Education, Science, and Culture of Japan.

1 Crystal RG, Bitterman PB, Rennard SI, Hance AJ, Keogh BA. Interstitial lung disease of unknown cause. Disorders characterized by chronic inflammation of the lower respiratory tract. N Engl f Med 1984;310:154-66.

2 Geist LJ, Hunninghake GW. Potential role of viruses in the pathogenesis of pulmonary fibrosis. Chest 1993;103. 119-20S.

3 Choo Q-L, Kuo G, Weiner AJ, Overvy LR, Bradley DW, Houghton $M$. Isolation of a cDNA clone derived from a blood-borne non-A, non-B viral hepatitis genome. Science 1989;244:359-62.

4 Giusti G, Pasquale G, Galante D, Russo M, Sardaro C, Gallo C, et al. Clinical and histological aspects of chronic HCV infection and cirrhosis. Hepatogastroenterology 1993 40:365-9

5 Ueda T, Ohta K, Suzuki M, Yamaguchi $M$, Hirai $K$ Horiuchi $\mathrm{T}$, et al. Idiopathic pulmonary fibrosis and high prevalence of serum antibodies to hepatitis $\mathrm{C}$ virus. Am Rev Respir Dis 1992;146:266-8.

6 Irving WL, Day S, Johnston IDA. Idiopathic pulmonary fibrosis and hepatitis C virus infection. Am Rev Respir Dis 1993;148:1683-4.

7 Thornthwaite JT, Seckinger D, Rosenthal P, Vazquez A. Characteristics of monoclonal antibody measurements in human peripheral blood. Ann N Y Acad Sci 1986;468. human peri.

8 The BAL Cooperative Group Steering Committee. Bronchoalveolar lavage constituents in healthy individuals, idiopathic pulmonary fibrosis, and selected comparison groups. Am Rev Respir Dis 1990;141:S169-202.

9 Pham BN, Mosnier JF, Walker F, Njapoum C, Bougy F, Degott C, et al. Flow cytometry CD4 +/CD8 + ratio of liver-derived lymphocytes correlates with viral replication in chronic hepatitis B. Clin Exp Immunol 1994;97:403-10.

10 Noguchi H, Kephart GM, Colby TV, Gleich GJ. Tissue eosinophilia and eosinophil degranulation in syndromes associated with fibrosis. Am $\mathcal{F}$ Pathol 1992;140:521-8.

11 Peterson MW, Monik M, Hunnighake GW. Prognostic role of eosinophils in pulmonary fibrosis. Chest 1987;92:51-6.

12 McFarlane IG, Smith HM, Johnson PJ, Bray GP, Vergane $D$, Williams $R$. Hepatitis $C$ virus antibodies in chronic active hepatitis: pathogenetic factor or false-positive result? Lancet 1990;335:754-7.

13 Houghton M, Weiner A, Han J, Kuo G, Choo Q-L. Molecular biology of the hepatitis $\mathrm{C}$ viruses: Implications for diagnosis, development and control of viral disease. Hepatology 1991;14:381-8.

14 Chemello L, Albert A, Rose K, Simmonds P. Hepatitis C serotype and response to interferon therapy. N Engl $\mathcal{G}$ Med 1994;330:143. 